\title{
Investigating market orientation and positioning in star-rated hotels in Ghana
}

\author{
Robert Ebo Hinson \\ Department of Marketing and Entrepreneurship, University of Ghana, \\ Accra, Ghana and University of the Free State Business School, \\ Bloemfontein, South Africa \\ Ibn Kailan Abdul-Hamid \\ Department of Marketing, University of Professional Studies, \\ Accra, Ghana and Department of Marketing and Entrepreneurship, \\ University of Ghana Business School, Accra, Ghana, and \\ Ellis L.C. Osabutey \\ Department of International Management and Innovation, \\ Middlesex University Business School, Middlesex University, London, UK
}

\begin{abstract}
Purpose - Market orientation and positioning have been widely recognized as organizational metrics linked to hotel performance. The purpose of this study is to offer the link among market orientation, positioning and hotel performance in Ghana's (luxury) hotel sector. It also reports on the joint influence of market orientation and positioning on hotel performance in the same sector.

Design/methodology/approach - Three hypotheses were investigated on the link between market orientation and hotel performance, positioning and hotel performance, and the joint effect of market orientation and positioning on hotel performance. A survey of star-rated (luxury) hotels in the capital city of Ghana was used. One hundred and five responses were used in the analysis. Descriptive statistics, exploratory factor analysis and hierarchical regression were used to test the three hypotheses.

Findings - All hypotheses were accepted. Market orientation and positioning jointly affect hotel performance, and the study provides hotel managers with suggestions on how to enhance their performance via market orientation and positioning.

Research limitations/implications - Market orientation, positioning, and performance measures focused on management perspectives without including perceptions of customers.

Originality/value - This study is one of the few attempts to systematically investigate the intertwined concepts of market orientation, positioning and performance in a developing economy hospitality context.
\end{abstract}

Keywords Positioning, Ghana, Market orientation, Hotel performance, Star-rated hotels

Paper type Research paper

(C) Robert Ebo Hinson, Ibn Kailan Abdul-Hamid and Ellis L.C. Osabutey. Published by Emerald Publishing Limited. This article is published under the Creative Commons Attribution (CC BY 4.0) licence. Anyone may reproduce, distribute, translate and create derivative works of this article (for both commercial and non-commercial purposes), subject to full attribution to the original publication and authors. The full terms of this licence may be seen at http://creativecommons.org/licences/by/4.0/ legalcode

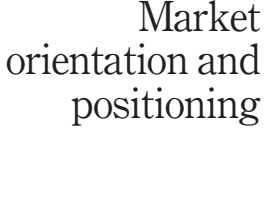

2629

Received 15 February 2016 Revised 22 May 2016

1 September 2016

26 October 2016

Accepted 4 February 2017

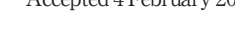




\section{$\mathrm{IJCHM}$ \\ 29,10}

\section{Introduction}

Hotels are the most significant and widely recognized variety of overnight accommodation globally (Holloway, 2001). Hotels sell offerings that comprise of a mixture of intangible service components and tangible goods components (Tajeddini, 2010). The intangible service components make the hotel service a challenging business to manage (Kuada and Hinson, 2014). The current rate of investment in the Ghanaian hotel sector seems to point to the business opportunities available in the sector (Narteh et al., 2013). International brands like Mövenpick Ambassador, Best Western and Holiday Inn have all pitched camp in Ghana's hotel sector. With the entry of these international players and more high-rated star hotels, competition in the Ghanaian hotel sector has become more intense (Narteh et al., 2013).

Some strategies that have been adopted by Ghanaian hotels to stay competitive have included location selection decisions, accessibility decisions, relationship marketing, human resource management, environmental management, delivering quality services and hotel internet usage (Ayeh, 2007; Adam and Amuquandoh, 2013; Narteh et al., 2013). Scholars have also highlighted some other strategies including relationship marketing (Kim et al., 2001; Narteh et al., 2013) and environmental management (Mensah, 2006, Mensah and Blankson, 2013). Hotels can also grow with a more customer-oriented approach like market orientation and positioning that can enhance hotel performance (Tajeddini, 2010). Although, there are contributions on hotel market orientation (Qu and Ennew, 2003; Sin et al., 2005; Wang et al., 2012) and hotel positioning (O'neill and Mattila, 2006; Lee and Back, 2010), these studies do not purposefully consider the complementary effects of market orientation and hotel positioning. This study therefore examines the joint effects of market orientation and positioning on the performance of star-rated (luxury) hotels in Ghana.

Market orientation is the degree to which a hotel is committed to the implementation of the marketing concept (Qu et al., 2005). Market orientation is a well-researched concept $(\mathrm{Qu}$ and Ennew, 2003; Sin et al., 2005; Altinay, 2010; Wang et al., 2012 Mahmoud, 2016), with scholars arguing that the hotel sector's utilization of marketing and its practices is slow compared with other commercial service sectors such as banking, insurance or retail distribution (Sin et al., 2005). According to Zhou et al. (2009), hotels are now paying close attention to the delivery of superior customer value to achieve better performance. An investigation into market orientation of hotels may improve the overall understanding of the market orientation concept in a service context (Qu and Ennew, 2003; Sin et al., 2005), particularly in developing economies like Ghana. Owing to the changing nature of Ghana's hotel landscape with the opening of an increasing number of multinational hotel chains in Ghana, and the fact that hotel growth can often be used as a proxy for tourism growth, the Ghanaian hotel sector provides a good context to explore how market orientation is adopted and practiced.

Market orientation and positioning strategies are not mutually exclusive and can be pursued simultaneously (Blankson et al., 2013). Thus, a combined implementation of market orientation and positioning is feasible and will generate superior performance as compared to when either market orientation or positioning is implemented individually (Blankson et al., 2013). The implementation of market orientation and positioning can result in both soft and hard benefits (Langerak, 2003; Zhou et al., 2009; Raju et al., 2011). An effective positioning strategy, executed with a firm's market orientation culture, will build a powerful brand (Fuchs and Diamantopoulos, 2010), and an inaccurately positioned brand with weak market orientations can bring failure for a firm (Blankson et al., 2013). This study focuses on joint effect of market orientation and positioning on hotel performance using star-rated (luxury) hotels in Ghana. 
The paper is set out as follows: the first section deals with introductory issues and the next section provides a discussion of market orientation and positioning leading to hypotheses development, as displayed in Figure 1. Next, the research methodology is discussed, including the instruments adopted to measure constructs. The results and analyses are then presented, which lead to a discussion of the findings relative to the existing literature. Finally, the paper concludes by presenting the conclusions, theoretical implications and practical implications, all of which enable the setting of an agenda for future research to enhance our understanding of market orientation and positioning in the hotel industry within the hospitality industry.

\section{Market orientation}

The market orientation construct is central to modern marketing decision-making and a frequently studied subject (Grinstein, 2008; Qu, 2009; Blankson et al., 2013; Mahmoud, 2016). There is a continuous interest in market orientation owing to the firm performance and market orientation nexus (Qu, 2009; Wang et al., 2012; Mahmoud, 2016). There are two distinguished complementary perspectives on market orientation: behavioural and cultural perspectives (Homburg and Pflesser, 2000; Langerak, 2003). The behavioural perspective holds that market orientation starts from market intelligence and it is a one-dimensional construct comprising three organization-wide activities: dissemination of marketing intelligence across departments, response based on market intelligence and market intelligence generation (Kohli and Jaworski, 1990; Diamantopoulos and Hart, 1993; Cadogan et al., 2003). The cultural perspective conceptualizes market orientation through competitor orientation, inter-function coordination and customer orientation. These components establish activities of market information attainment and propagation, and the harmonized manufacture of value for the clientele (Langerak, 2003). Market orientation for this study will be seen chiefly as the organizational philosophy that most efficiently and effectively creates the behaviors necessary for the creation of superior value for consumers resulting from superior firm performance (Narver and Slater, 1990). This definition has been used by previous researchers (Langerak, 2003; Agarwal et al., 2003; Sørensen, 2009; Mitchell et al., 2010). The Narver and Slater perspective is adopted for this study because market

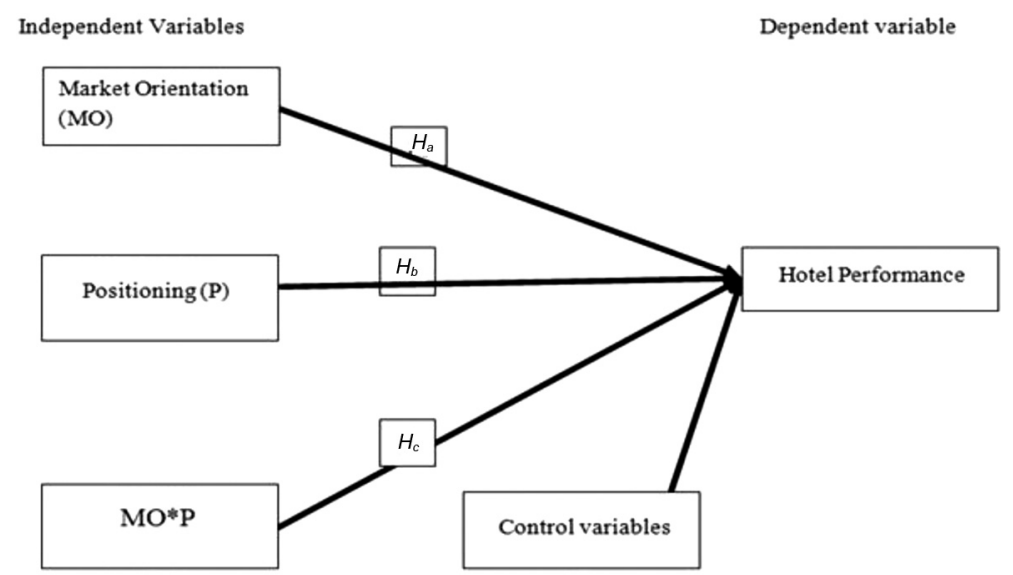

Source: Authors own development based on literature review

Figure 1. Conceptual model 
IJCHM

29,10

orientation has been theorized in terms of behaviors and captures the main aspects of Kohli and Jaworski's conceptualization (Hooley et al., 2003; Blankson et al., 2013).

\section{Positioning}

Marketing strategy is put up on segmentation, targeting and positioning (Kotler and Keller, 2012). Accordingly, a firm realizes the diverse groups and needs in consumer markets, aims for customers who can be satisfied in a superior way and then places its offering so that the target market identifies the firm's unique offerings and images. Positioning, therefore, helps customers know the real difference among competing products and/or services so that they can choose the one that is of most value to them (Cravens, 2000). Effective positioning begins with differentiating a company's offering, such that it gives consumers more value, and then, steps are taken to deliver this value, along with communicating this position, to the target consumers (Kotler and Armstrong, 2006). Positioning is a process of crafting a firm's image and offering to dwell in a unique place in the mind of the aimed customer market with the attendant result of creating a buyer-concentrated value scheme that would ease customer purchases (Asikhia, 2010; Kotler and Keller, 2012). Importantly, positioning is closely linked to business strategy (Cravens, 2000; Blankson and Crawford, 2012). The consequence of using a positioning strategy is the successful creation of a buyer-focused value offer - a persuasive reason why the target market should adopt or use a product (Kotler, 2003). Also, a company's long-term competitive advantage is a consequence of their positioning activities (Gursoy et al., 2005; Blankson and Crawford, 2012). It could be argued that hotels who want to remain competitive might consider adopting proactive positioning practices.

Consumer and managerial perspectives are the two positioning perspectives discussed in the academic literature (Blankson and Kalafatis, 1999; Kotler et al., 2010). A consumer perspective refers to what a consumer actually thinks about a firm, independent of the influence of that firm, while a managerial perspective considers what customers think after managers have influenced their thoughts. The strategic management literature argues that firms that choose clear positioning tend to enjoy returns and survive turbulent environments (Spanos and Lioukas, 2001; Kim et al., 2008). Moreover, the importance of positioning to customer satisfaction, customer loyalty, customer retention and overall business performance has been well-studied (cf. Gruca and Rego, 2005; Kim and Kim, 2005).

\section{Market orientation and positioning}

Market orientation and positioning are both central to marketing management decisionmaking and strategy (Kotler and Keller, 2012). Positioning is the proactive, deliberate and iterative utilization of market-oriented strategies that modify consumers' perceptions about a hotel's offering (Blankson et al., 2013). Studies on positioning have focused on positioning strategies, the effectiveness of positioning strategies, the impact of positioning on performance, the link between positioning strategies and market orientation and their joint effect on business performance (Blankson and Kalafatis, 2007; Blankson and Crawford, 2012; Blankson et al., 2013). A review of the extant literature proposes that only few publications have studied the combination of market orientation and other strategic orientation relationships (Grinstein, 2008). Some combinations that have been examined include: market orientation and entrepreneurship (Atuahene-Gima and Ko, 2001), market orientation and innovation (Hult and Ketchen, 2001), and market orientation and positioning (Blankson et al., 2013). The importance of using market orientation and positioning strategies for improved firm performance has been fairly well acknowledged (cf. Hooley et al., 2004; Blankson et al., 2013) in the literature. 


\section{Hypotheses development}

Market orientation and hotel performance

Market orientation has been argued to be important to creating continuous superior performance for firms (Kohli and Jaworski, 1990; Narver and Slater, 1990). Market orientation is a crucial capability that has the prospective to transform existing resources into superior performance (Brik et al., 2011). Hotels that are responsive to stakeholders' needs coordinate their internal activities with performance and manage their competitive landscape would achieve an improvement in their operations (McKitterick, 1958). Grinstein (2008) suggests that market orientation considerably contributes more than other strategic orientations to firm performance. In the Ghanaian business landscape, Kuada and Buatsi (2005), Hinson et al. (2008), Mahmoud and Hinson (2012), and Mahmoud (2016) have contended that market orientation relates positively with firm performance. Agarwal et al. (2003) also reported a positive association between a hotel's market orientation and its performance. With the fierce competitive nature of the Ghanaian hotel sector (Narteh et al, 2013), this study proposes that:

H1. A hotel's market orientation positively affects its performance.

\section{Positioning and hotel performance}

Marketing scholars have acknowledged that a well-positioned offering may achieve longterm success for its firms (Blankson and Kalafatis, 1999; Kotler and Keller, 2012; Blankson and Crawford, 2012). Positioning also allows firms to survive in a turbulent environment, thus influencing the performance of those firms (Kim et al., 2008). Kalafatis et al. (2000) concluded that there is a positive link between a firm's positioning strategy and its performance. Hooley et al. (2001) reported that a greater performance is linked to high quality positioning. In addition, Blankson and Crawford (2012) argued for a direct link between positioning and firm performance. Blankson et al. (2013) acknowledged that positioning contributes to a firm's benefit. Positioning is also reported to be a key driver of success in the hotel sector (Brady et al, 2005; Hanson et al., 2009). Thus, this study postulates that:

H2. A hotel's positioning strategy positively affects its performance.

\section{The interactional effects of positioning and market orientation on hotel performance}

Market orientation and positioning are complementary to one another and they contribute to competitive advantage when they interact in ways that generate superior performance (Blankson et al., 2013; Morgan et al., 2009). A market-oriented and well-positioned hotel would outperform competitors lacking market orientation or positioning strategies (Hooley et al., 1999; Blankson et al., 2013). Similarly, a well-positioned hotel offering that takes cognizance of the needs, wants and aspirations of a hotel guest would lead to improved performance (Fuchs and Diamantopoulos, 2010). While Blankson et al. (2013) conceptually predicted a connection between market orientation and positioning on firm performance, this study predicts that:

H3. The interaction between a hotel's market orientation and positioning strategy positively affect its performance.

\section{Research methodology}

A quantitative research design was utilized in testing and examining the link between hotel performance and market orientation, positioning and hotel performance, and the

Market
orientation and
positioning

2633

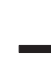


IJCHM

29,10

joint effect of positioning and market orientation on hotel performance (cf. Boso et al., 2013). Star-rated hotels were contacted in this study because they represent luxury and class among hotels, and have a highly competitive nature (Narteh et al., 2013). Star-rated hotels in Accra were used, as Accra is the capital of Ghana and has the highest number of star-rated hotels (Narteh et al., 2013). The hotel ratings represent the quality of hotel services or facilities provided (the rated hotels used ranged from 1 to 5). This is conventionally used to rank hotels on performance and client services (market orientation) and also utilized by the Ghana Hotel Association (GHA) in ranking hotels (Ghana Hotels Association, 2013). Thus, a low rating shows low delivery services, while a high rating shows a high delivery of hotel services. Standards are prescribed from time to time by the Ghana Tourism Authority with the aim of encouraging hotels to meet international standards (Ghana Hotels Association, 2013). The study population was 110 star-rated hotels operating in the Greater Accra Region of Ghana. According to the 2013 GHA list of hotels in Ghana, only 110 hotels in Accra were star-rated, reflecting the use of only 110 star-rated hotels. Executives at the hotels were used as the empirical focus. This is because they were deemed to have in-depth knowledge about the marketing orientation and performance of their firms. Three questionnaires were sent to each of the 110 star-rated hotels; 210 usable questionnaires were retrieved and used in the analysis. Respondents used their firm-level experiences (at the time of data collection) as the basis for their responses. In doing so, individual executive perceptions reflected firm orientation and performance. Following Kohli and Jaworski (1990), the aggregates of every two responses from a hotel were used to represent the hotel (210 responses were reduced to 105 responses). Therefore, one market orientation score was used for each hotel. At the end, only 105 responses were used for further analysis in the study. Crosssectional data were used in the study to collect information from executives because it is the most common technique and provides inexpensive, quick, accurate and efficient means of collecting information about a population (Robson, 2002; Zikmund and Babin, 2010). The executives at these hotels who are exposed to strategic decisions of these hotels were engaged in the study (Qu and Ennew, 2003).

Subjective scales of hotel performance (customer satisfaction, customer loyalty, and customer retention) were used in measuring business performance (Qu and Ennew, 2003; Urde et al., 2013). Urde et al., (2013) concluded that customer loyalty, customer retention and customer satisfaction are performance metrics of market orientation. Market orientation was measured using Narver and Slater's (1990) instrument of competitor orientation, interfunctional coordination and customer orientation, because this scale is both operationally and conceptually appealing (Blankson et al., 2013). The Narver and Slater's (1990) scale captures the main aspects of Kohli and Jaworski's responsiveness, dissemination and intelligence gathering construct while assessing cultural factors concurrently (Hooley et al., 2003; Blankson et al., 2013). Sørensen (2009) also pointed out that competitors, customers and inter-functional coordination are key constituents of market orientation and it provides diverse types of information for decision-making. Positioning was measured using the Blankson and Kalafatis (2004) instrument. Blankson and Kalafatis' (2004) instrument was adopted as it satisfies the call for consumer-based positioning strategies (Fill, 1999) and satisfies the criticisms leveled against extant conceptually driven and managerial-oriented typologies of positioning strategies (Kalafatis et al., 2000). Following Qu and Ennew (2003), firm size, market turbulence and competitor intensity were controlled for. The items measuring market orientation, positioning, hotel performance, market turbulence and competitor intensity are provided for in the Appendix. 


\section{Results and analyses}

To understand and test the hypotheses that market orientation influences hotel performance, positioning influences hotel performance, and the joint effect of market orientation and positioning influences hotel performance, a normality and multicollinearity test, an exploratory factor analysis, summated scales and a hierarchical regression were conducted on the data collected (Hair et al., 2008). The study considered a hotel's rating, the duration of an employee working with the hotel and the number of employees of a hotel as demographic characteristics. Majority of the hotels had an employee size of less than 25. Table I provides further insights into the demographic characteristics of the respondents. As a general rule of thumb, assumption of data normality can be established when skew values fall within the range of -1 to +1 (Hair et al., 2006) and a kurtosis value falls within -3 to +3 (Hair et al., 1998). From Table I, the skew value for each construct is within the range of normality for data. Also, the kurtosis values are within the +3 and above -3 limits. These results suggest that the constructs are normal for further analysis. Table I also provides measures on the collinearity (multi) of constructs. With VIF values of less than 10, it means that the results do not have collinearity (Hair et al., 2006). The constructs can, therefore, be used for further analysis.

\begin{tabular}{|c|c|c|c|c|}
\hline $\mathrm{S} / \mathrm{N}$ & Characteristics & Indicators & Frequency & $(\%)$ \\
\hline \multirow[t]{6}{*}{1} & \multirow[t]{6}{*}{ Hotel rating } & 1Star & 38 & 36.2 \\
\hline & & 2 Star & 46 & 43.8 \\
\hline & & 3 Star & 14 & 13.3 \\
\hline & & 4 Star & 5 & 4.8 \\
\hline & & 5 Star & 2 & 1.9 \\
\hline & & Total & 105 & 100 \\
\hline \multirow[t]{4}{*}{2} & \multirow{4}{*}{ Department } & Marketing & 63 & 60.5 \\
\hline & & Housekeeping & 34 & 31.9 \\
\hline & & Finance & 8 & 7.6 \\
\hline & & Total & 105 & 100 \\
\hline \multirow[t]{5}{*}{3} & \multirow{5}{*}{ Length of working with hotel } & Less than a year & 43 & 41 \\
\hline & & $1-5$ years & 24 & 22.8 \\
\hline & & $6-10$ years & 22 & 21 \\
\hline & & More than 10 years & 16 & 15.2 \\
\hline & & Total & 105 & 100 \\
\hline \multirow[t]{3}{*}{4} & \multirow[t]{3}{*}{ Employee size } & Less than 25 & 33 & 31.4 \\
\hline & & $25-50$ & 72 & 68.6 \\
\hline & & Total & 105 & 100 \\
\hline \multirow[t]{6}{*}{5} & \multirow{6}{*}{ Normality test for variables } & Constructs & Skewness & Kurtosis \\
\hline & & Positioning & -0.304 & -0.805 \\
\hline & & Market orientation & -0.524 & 0.109 \\
\hline & & Competitor intensity & -0.624 & -0.500 \\
\hline & & Market turbulence & -0.468 & -0.453 \\
\hline & & Hotel performance & -0.340 & -0.831 \\
\hline \multirow[t]{5}{*}{6} & \multirow[t]{5}{*}{ Multicollinearity statistics } & Constructs & Tolerance & VIF \\
\hline & & Positioning & 0.129 & 7.734 \\
\hline & & Market orientation & 0.223 & 4.487 \\
\hline & & Competitor intensity & 0.404 & 2.474 \\
\hline & & Market turbulence & 0.438 & 2.286 \\
\hline
\end{tabular}

Market

orientation and positioning

2635

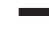




\section{$\mathrm{IJCHM}$ \\ 29,10}

\section{Exploratory factor analysis}

An exploratory factor analysis (EFA) was used to identify factors that explain the correlations among a set of variables (Malhotra and Dash, 2011). The EFA was executed on market orientation, positioning and business performance. Consequently, market orientation had 15 items measuring its three dimensions of competitor orientation, customer orientation and inter-functional co-ordination (Narver and Slater, 1990). A Kaiser-MeyerOlkin (KMO) is an indicator of selection appropriateness that affords an index between 0 and 1 , describing the ratio of difference among the variables that might be shared variance. A KMO of 0.769 and a cumulative variance explained of 61 per cent was recorded. A KMO of more than 0.7 means that the data were good for factor analysis, and the cumulative variance explained shows that the factors explained 61 per cent of the data (Hair et al., 2006). A cumulative variance explained of 0.5 and above was preferred. Both KMO and cumulative variance indicators were satisfied.A principal component extraction with varimax rotation was executed. Three factors immerged with eigenvalues more than one. These were selected for further analysis. These factors represented the original factors of Narver and Slater (1990), with a few items changing factors. So, the original customer orientation, competitor orientation and inter-functional co-ordination were still identified as factors that together measured market orientation in the Ghanaian hotel sector. In all, these factors had 11 items and their Cronbach's alpha was 0.804 . This alpha value is higher than the 0.7 benchmark provided by Nunnally (1978). Because this study is interested in measuring only market orientation and not its antecedents, the average of the 11 items was computed to represent market orientation for further analysis (Hair et al., 2006). This average value represented market orientation in the subsequent analysis.

Positioning was measured with 22 items representing 7 positioning strategies provided by Blankson and Kalafatis (2004). A KMO of 0.760 and a cumulative variance explained 71.4 per cent of data. Similarly, the KMO and total variance explained are above the required levels. Therefore, a principal component analysis with varimax rotation was extracted. Six factors were recorded; however, Factors 4, 5, and 6 recorded 2, 2 and 1 item loading, respectively. Following Blankson and Kalafatis (2004), an attempt was made to merge these factors with other factors; however, the factors appeared not to be conceptually related. So these factors were eliminated from further analysis (Hair et al., 1998; Blankson and Kalafatis, 2004). Therefore, positioning was measured on three factors. These factors were brand name, top of the range and attractiveness. According to Blankson and Kalafatis (2004), naming factors can be done by observing the item with the highest loading to the factor, and this has informed the naming of the factors in this study. These three factors combined had a Cronbach's alpha of 0.857 with 13 items combined. The reliability is equally above the required level of 0.7 . Therefore, the average of the 13 items is computed to represent positioning for further analysis (Hair et al., 2006).

The study used subjective measures like customer satisfaction, customer loyalty and customer retention in measuring hotel performance (Agarwal et al., 2003; Urde et al., 2013). These constructs had a total of 11 items. A principal component analysis with varimax rotation reduced the items to two factors with a KMO of 0.746 and cumulative variance explained 67.3 per cent of the data. Correspondingly, this test supported the factor analysis. Interestingly, the three original subjective measures have been reduced to two factors, following Blankson and Kalafatis' (2004) guide on naming factors. Customer retention and customer satisfaction were the two factors used for further analysis. These factors loaded a total of six items with Cronbach's alpha of 0.788 , encouraging the use of these two factors for hotel performance. The average of these six items was calculated to represent hotel performance in the analysis (cf. Hair et al., 2006) (Tables II and III). 


\begin{tabular}{|c|c|c|c|c|c|c|c|c|c|c|}
\hline \multirow[b]{2}{*}{ Component } & \multicolumn{3}{|c|}{ Initial eigenvalues } & \multicolumn{3}{|c|}{$\begin{array}{l}\text { Extraction sums of squared } \\
\text { loadings }\end{array}$} & \multicolumn{3}{|c|}{$\begin{array}{c}\text { Rotation sums of squared } \\
\text { loadings }\end{array}$} & \multirow{2}{*}{$\begin{array}{r}\text { Market } \\
\text { orientation and } \\
\text { positioning }\end{array}$} \\
\hline & Total & $\begin{array}{l}(\%) \text { of } \\
\text { variance }\end{array}$ & $\begin{array}{l}\text { Cumulative } \\
(\%)\end{array}$ & Total & $\begin{array}{c}(\%) \text { of } \\
\text { variance }\end{array}$ & $\begin{array}{l}\text { Cumulative } \\
(\%)\end{array}$ & Total & $\begin{array}{l}(\%) \text { of } \\
\text { variance }\end{array}$ & $\begin{array}{l}\text { Cumulative } \\
(\%)\end{array}$ & \\
\hline \multicolumn{11}{|c|}{ Market orientation } \\
\hline 1 & 3.876 & 35.237 & 35.237 & 3.876 & 35.237 & 35.237 & 2.933 & 26.660 & 26.660 & \\
\hline 2 & 1.582 & 14.380 & 49.618 & 1.582 & 14.380 & 49.618 & 1.929 & 17.534 & 44.194 & 263 \\
\hline 3 & 1.254 & 11.398 & 61.015 & 1.254 & 11.398 & 61.015 & 1.850 & 16.822 & 61.015 & \\
\hline 11 & 0.270 & 2.455 & 100.000 & & & & & & & \\
\hline \multicolumn{11}{|l|}{ Positioning } \\
\hline 1 & 5.593 & 31.070 & 31.070 & 5.593 & 31.070 & 31.070 & 3.038 & 16.877 & 16.877 & \\
\hline 2 & 2.018 & 11.213 & 42.283 & 2.018 & 11.213 & 42.283 & 2.789 & 15.493 & 32.370 & \\
\hline 3 & 1.767 & 9.816 & 52.100 & 1.767 & 9.816 & 52.100 & 2.441 & 13.563 & 45.933 & \\
\hline 4 & 1.304 & 7.244 & 59.343 & 1.304 & 7.244 & 59.343 & 1.679 & 9.330 & 55.263 & \\
\hline 5 & 1.160 & 6.445 & 65.788 & 1.160 & 6.445 & 65.788 & 1.647 & 9.150 & 64.412 & \\
\hline 6 & 1.007 & 5.592 & 71.380 & 1.007 & 5.592 & 71.380 & 1.254 & 6.967 & 71.380 & \\
\hline 18 & 0.148 & 0.820 & 100.000 & & & & & & & \\
\hline \multicolumn{11}{|c|}{ Performance } \\
\hline 1 & 2.957 & 49.287 & 49.287 & 2.957 & 49.287 & 49.287 & 2.091 & 34.851 & 34.851 & \\
\hline 2 & 1.079 & 17.989 & 67.275 & 1.079 & 17.989 & 67.275 & 1.945 & 32.424 & 67.275 & \\
\hline 6 & .323 & 5.379 & 100.000 & & & & & & & \\
\hline \multicolumn{10}{|c|}{$\begin{array}{l}\text { Extraction Method: Principal component } \\
\text { analysis }\end{array}$} & $\begin{array}{r}\text { Total variance } \\
\text { explained }\end{array}$ \\
\hline
\end{tabular}

\begin{tabular}{lcrr}
\hline Study constructs & Cronbach's alpha & Nof items & \\
\hline Market orientation & 0.804 & 11 & Table III. \\
Positioning & 0.857 & 13 & Reliability statistics \\
Business performance & 0.788 & 6 & \\
\hline
\end{tabular}

Correlation values, mean and standard deviations (SD) are presented in Table IV. The correlation values are found to determine the relationships between the five constructs. There are significant relationships between all the five constructs. These findings suggest that market orientation, positioning, competitor intensity, and market turbulence, all have significant relationships with hotel performance. Therefore, a change in any of these constructs may influence hotel performance (Hair et al., 2008).

\section{Market orientation and hotel performance relationship}

To test the relationship between market orientation and hotel performance, a regression analysis was conducted after controlling for hotel rating, competitor intensity and market turbulence. Table $\mathrm{V}$ presents, under Model 3, the multiple regressions for market orientation, positioning and hotel performance relationships. The finding showed that market orientation $(\mathrm{b}=0.653, p<0.01$ ) has a significant and positive relationship with hotel performance, supporting $H 1$. This finding suggests that a percentage ( 1 per cent) increase in 
IJCHM

29,10

a hotel's market orientation will result in about 65 per cent increase in hotel performance. Also, the change in $R^{2}$ on Table V shows that market orientation contributes 0.297 to the $R^{2}$ of 0.840 in the hierarchical regression. This result implies that market orientation explains about 30 per cent of the total variation (0.840) explained by market orientation and positioning (Hair et al., 2006).

\section{8}

\section{Positioning and hotel performance relationship}

The relationship between positioning and hotel performance was also tested under Model 3 of the hierarchical regression, as shown in Table V. The multiple regression results show that $\mathrm{P}(\mathrm{b}=0.560, p<0.01)$ has a significant and positive relationship with hotel performance, supporting $H 2$. This finding means a percentage (1 per cent) increase in a hotel's positioning will result in about 56 per cent increase in a hotel's performance. Similarly positioning also contributes 0.025 to the $R^{2}$ of 0.865 recorded for Model 3. Thus, positioning explains about 2.5 per cent of the total variation (0.865) explained by market orientation and positioning.

Table IV.

Correlation, means and standard deviations

\begin{tabular}{|c|c|c|c|c|c|c|c|c|}
\hline Study constructs & Mean & SD & 1 & 2 & 3 & 4 & 5 & 6 \\
\hline 1. Hotel performance & 3.85 & 0.68 & 1 & & & & & \\
\hline 2. Market orientation & 3.9 & 0.54 & $0.905^{* *}$ & 1 & & & & \\
\hline 3. Positioning & 3.94 & 0.56 & $0.886^{* *}$ & $0.865^{* *}$ & 1 & & & \\
\hline 4. Competitor intensity & 3.97 & 0.788 & $0.549 * *$ & $0.506^{* *}$ & $0.718 * *$ & 1 & & \\
\hline 5. Martket turbulence & 3.92 & 0.777 & $0.637^{* * *}$ & 0.606 ** & $0.724 * *$ & $0.634 * *$ & 1 & \\
\hline 6. Hotel rating & 4.10 & 0.891 & $0.397^{* *}$ & $0.395^{* *}$ & $0.418 * *$ & $0.150^{*}$ & 0.09 & 1 \\
\hline
\end{tabular}

\begin{tabular}{|c|c|c|c|c|c|c|c|c|}
\hline \multirow[b]{3}{*}{ Independent variables } & \multicolumn{8}{|c|}{ Hotel performance } \\
\hline & \multicolumn{2}{|c|}{ Model 1} & \multicolumn{2}{|c|}{ Model 2} & \multicolumn{2}{|c|}{ Model 3} & \multicolumn{2}{|c|}{ Model 4} \\
\hline & B & $\mathrm{T}$ & $\mathrm{B}$ & $\mathrm{T}$ & B & $\mathrm{T}$ & B & $\mathrm{T}$ \\
\hline \multicolumn{9}{|l|}{ Step 1} \\
\hline Constant & 0.52 & $2.35 * *$ & 2.97 & $16.36^{*}$ & 3.93 & $16.88^{*}$ & 3.95 & $17.02 *$ \\
\hline Competitor intensity & 0.17 & $3.16^{*}$ & 0.066 & $2.06 * *$ & -0.051 & -1.45 & -0.06 & -1.60 \\
\hline Market turbulence & 0.42 & $7.94 *$ & 0.10 & $2.86^{* * *}$ & 0.026 & 0.74 & 0.018 & 0.52 \\
\hline Hotel rating & 0.25 & $6.78^{*}$ & 0.05 & $2.29 * *$ & 0.006 & 0.26 & 0.009 & 0.36 \\
\hline $\begin{array}{l}\text { Step } 2 \\
\text { Add Market orientation (MO) }\end{array}$ & & & 0.97 & $19.48 *$ & 0.65 & $9.54^{*}$ & 0.66 & $9.68^{*}$ \\
\hline $\begin{array}{l}\text { Step } 3 \\
\text { Add: Positioning (P) }\end{array}$ & & & & & 0.56 & $6.15^{*}$ & 0.59 & $6.38^{*}$ \\
\hline Step 4 & & & & & & & & \\
\hline Add $\mathrm{MO} \times \mathrm{P}$ & & & & & & & 0.094 & $1.76^{* * * *}$ \\
\hline$R^{2}$ & 0.543 & & 0.840 & & 0.865 & & 0.867 & \\
\hline$\Delta R^{2}$ & 0000 & & 0.297 & & 0.025 & & 0.002 & \\
\hline F & 81.53 & & 268.37 & & 260.88 & & 220.15 & \\
\hline df. & 101 & & 100 & & 99 & & 98 & \\
\hline$P$ & 0.000 & & 0.000 & & 0.000 & & 0.000 & \\
\hline
\end{tabular}


The interactional effect of market orientation and positioning on hotel performance

The findings show that market orientation and positioning interact with each other $(\mathrm{b}=$ $0.094, p<0.1)$ to positively relate to hotel performance, supporting $H 3$. The results suggest that hotels that increase a percentage (1 per cent) of their combination of market orientation and positioning strategies will experience a 9 per cent increase in hotel performance. Also, their combined contribution to the $R^{2}$ of 0.867 is 0.002 .

\section{Control variables}

The study controlled for hotel rating, competitor intensity and market turbulence. All these variables recorded insignificant relationships. In Table V, under Model 4, it can be observed that all these control variables do not have significant contributions to hotel performance. The three control variables recorded an $R^{2}$ of 0.543 . Hotel rating was not significant ( $\mathrm{b}=$ $0.008)$, competitor intensity also was not significant $(\mathrm{b}=-0.062)$ and market turbulence equally was not significant $(b=0.017)$.

\section{Discussion of findings}

The study found that market orientation is positively related to hotel performance, which is similar to the findings from Kirca et al., 's (2005) study, in which a meta-analysis was conducted on the market orientation and firm performance connection. In Ghana, Kuada and Buatsi (2005), Hinson et al. (2008), Mahmoud et al. (2010) and Mahmoud (2016) have all reported a positive link between market orientation and firm performance. Whilst Agarwal et al. (2003) also found positive associations between hotel performance and market orientation, this finding also supports prior studies (Kohli and Jaworski, 1990; Narver and Slater, 1990; Sørensen, 2009) in different sectors. It also confirms previous studies on hotel market orientation (Qu and Ennew, 2003; Agarwal et al., 2003) that found positive relationships between market orientation and hotel performance. Our findings also support similar studies on market orientation and other strategic orientations (Olavarrieta and Friedmann, 2008; Morgan et al., 2009) that reported positive relationships between firm performance and market orientation. Specifically, Olavarrieta and Friedmann (2008) reported a substantial influence of market orientation on firm performance. Equally, Morgan et al. (2009) concluded that American firms' market orientations had a positive effect on their performance. Cano et al. (2004) also concluded that the link between business performance and market orientation is positive worldwide. Besides, researchers have found that the market orientation and business performance relationship is stronger when firm performance is measured subjectively (Kirca et al., 2005; Haugland et al., 2007).

The study also revealed that positioning strategy positively relates with hotel performance, which is similar to the findings of Porter (1996) and Kalafatis et al. (2000) who reported a positive link between positioning and business performance. Blankson and Crawford (2012) and Miles and Mangold (2005) also recognized a link between positioning and firm performance. The result of this study indicates that a hotel's positioning strategy explains its performance. This finding is supported by scholars who believe that a position chosen by a firm allows it to enjoy returns and assists it in surviving turbulent environments (Spanos and Lioukas, 2001; Kim et al., 2008). Blankson and Crawford (2012) reported that the positioning of a retail service firm influences the return on investment (ROI), sales, profit, consumer perceptions and market share of that firm. In addition, Hooley et al. (2001) also found that greater performance is linked with more distinguishing and quality positioning.
Market
orientation and
positioning

2639 
IJCHM

29,10

2640

The study also found that market orientation and positioning interact to positively relate with hotel performance. Thus, the interaction of market orientation and positioning has a positive and significant effect on hotel performance. The results might be due to the conclusions of earlier researchers who have posited that firms that adopt market orientation practices become more successful with positioning efforts (Langerak, 2003; Blankson et al., 2013), hence achieving superior performance than others. Nicovich et al. (2007) examined concerns connecting market orientation and firm performance conceptually and empirically.

The study found that market orientation works alongside a firm's position in a market place and competitive strategy, but does not directly influence a firm's performance (Nicovich et al., 2007). Researchers like Baker and Sinkula (1999), Atuahene-Gima and Ko (2001), and Grinstein (2008) have argued that businesses who utilized market orientation and alternative strategic orientations like positioning are likely to perform better than firms adopting only market orientation. By looking at market orientation, positioning both separately and interactively, our study shows that market orientation explains about thirty per cent of the total variation, positioning explains about 2.5 per cent and their combined contribution only explains 0.2 percent. This approach allows us to observe the significant contribution of market orientation to firm performance.

\section{Conclusions}

The focus of this study was to empirically show the linkage between market orientation and positioning, separately and interactively, with performance in Ghana's (luxury) hotel sector. Hotels that use market orientation and positioning strategies well would achieve superior performance than their competitors. We argue that hotels should strive to identify the needs and wants of their customers, collect intelligence on competitors and their activities, and ensure that all departments are engaged in the analysis of competitor and customer needs to improve on their offerings. Hotels that adopt dependable positioning strategies may enjoy improved performance. Consequently, brand name, top of the range and attractiveness are hotel positioning strategies that may improve hotel performance. Managers of hotels must continue to engage with clients to identify their needs and monitor changes in customer preferences. This would give market-oriented hotels some competitive advantage owing to their understanding of customers and their preferences. However, only appreciating customer needs and wants might not be enough, so the other aspects of market orientation are equally relevant in benefiting from market orientation fully. Hotels must consider monitoring and understanding their competitors' activities via market intelligence to secure a competitive advantage. This aspect of market orientation affords hotels information on their competitors. Competitor information could deliver competitive advantage to a firm.

Our findings suggest a precedence of marketing orientation as integral to firm positioning. A firm's positioning would improve if its marketing orientation activities increase. Developing coordinated responses within the hotel and viewing all departments as equally important is critical in creating customer value. In addition to identifying customer needs and collecting information on competitor activities, hotels should disseminate such information to all departments. It is important that all departments be seen as relevant contributors to customer value. Firms successful in implementing market orientation and developing a good positioning strategy stand the greatest chance of outperforming their competitors in Ghana's hotel sector. Hotels should therefore adopt market orientation first before considering positioning strategy. When these strategic orientations are properly implemented, hotels will benefit from more satisfied and retained customers. To the extent that positioning strategies like top of the range, brand name and attractiveness seem to 
provide improved performance in the hotel sector, managers in Ghana's hotel sector may consider positioning their hotels along these attributes.

\section{Theoretical implications}

Our findings suggest that, theoretically, researchers who emphasize positioning strategies as important for firm performance cannot ignore the significant role played by market orientation and that without a strategic and sustainable market orientation; firms may not 2641 be able to create and/or maintain long-term positioning (cf. Mahmoud, 2016). Our theoretical contribution accentuates that the link between market orientation and firm performance is positive in both developed and developing country settings and agrees with the study of Cano et al. (2004) which concluded that the link between firm performance and market orientation is positive worldwide. Our findings suggest that for firms in an industry that serves both local and international customers, such as high-end star-rated hotels, the interactions between market orientation, positioning and firm performance are consistent whether in a developed or developing country. Therefore, industries that particularly target more foreign clients, such as tourism and the hotel industry, have a more international orientation which means that market orientation and positioning separately and interactively influence firm performance. This makes an international orientation the overriding factor that determines the performance of such firms. Such firms need to overcome institutional constraints to meet the requirements of their more internationally oriented customer base.

\section{Practical implications}

Firms in the hospitality industry that are seeking to improve their positioning should understand the importance of their market orientation. Because consumer perceptions influence positioning, managers need to understand that implementing marketing concepts is indispensable. This requires that managers and employees should have the marketing orientation that is inadvertently imbedded in organizational culture to influence firm performance. The organizational culture would create the necessary behaviors for superior performance which would influence customer perceptions. Therefore, even though integrated marketing communication is important, it would be more effective when the marketing orientations of firms are good. Hospitality industry firms, such as hotels, who aim to improve performance, should consistently strive to understand that their customers have a more international orientation. This means that more needs to be done to understand the expectations of such customers. Managers should aim at delivering or exceeding customer expectations, which will inevitably improve perceptions and therefore market orientation. The ability of customers to use websites such as trip advisors etc. to ascertain the perceptions of customers about firms makes it more important that firms should continuously strive to deliver exceptional customer service. Positioning is also very important, given that customers know what to expect from the firm. Because good marketing orientation improves positioning, which influences customer perceptions, managers need to also ensure that their positioning is consistently communicated to the customers. This emphasizes the need for such firms to conduct customer satisfaction surveys to ensure that their services are meeting the required standards. A good understanding of customer needs and good communication between service providers and customers would invariably lead to good performance. 


\section{$\mathrm{IJCHM}$ 29,10}

\section{Limitations and future research}

Although our study has improved our understanding of the effect of market orientation and positioning separately and interactively in a developing country and the sub-Saharan African context, it is a one-country study. A multi-country and comparative study could provide further nuances on the effect of market orientation and positioning on business performance. Our study emphasizes the overall contribution of marketing orientation, in particular on firm performance, but studies which isolate the activities that firms engage in to develop their market orientations and positioning may show regional variations influenced by cultural and institutional differences. In addition, this study did not report on antecedents such as customer orientation, competitor orientation, inter-functional coordination, brand name, top of the range, attractiveness, customer satisfaction and customer retention. Future studies may focus on these antecedent factors. Our questionnaires were administered to executives who used their firm-level experiences as responses; future research could also consider responses from customers.

\section{References}

Adam, I. and Amuquandoh, F.E. (2013), "Dimensions of hotel location in the Kumasi Metropolis, Ghana", Tourism Management Perspectives, Vol. 8, pp. 1-8.

Agarwal, S., Krishna Erramilli, M. and Dev, C.S. (2003), "Market orientation and performance in service firms: role of innovation", Journal of Services Marketing, Vol. 17 No. 1, pp. 68-82.

Altinay, L. (2010), "Market orientation of small ethnic minority-owned hospitality firms", International Journal of Hospitality Management, Vol. 29 No. 1, pp. 148-156.

Asikhia, O. (2010), "Customer orientation and firm performance among Nigerian small and medium scale businesses”, International Journal of Marketing Studies, Vol. 2 No. 1, p. 197.

Atuahene-Gima, K. and Ko, A. (2001), "An empirical investigation of the effect of market orientation and entrepreneurship orientation alignment on product innovation", Organization Science, Vol. 12 No. 1, pp. 54-74.

Ayeh, J.K. (2007), "Determinants of internet usage in Ghanaian hotels: the case of the Greater Accra Region (GAR)", Journal of Hospitality and Leisure Marketing, Vol. 15 No. 3, pp. 87-109.

Baker, W.E. and Sinkula, J.M. (1999), "The synergistic effect of market orientation and learning orientation on organizational performance", Journal of the Academy of Marketing Science, Vol. 27 No. 4, pp. 411-427.

Blankson, C. and Crawford, J.C. (2012), "Impact of positioning strategies on service firm performance", Journal of Business Research, Vol. 65 No. 3, pp. 311-316.

Blankson, C. and Kalafatis, S.P. (1999), "Issues and challenges in the positioning of service brands: a review", Journal of Product \& Brand Management, Vol. 8 No. 2, pp. 106-118.

Blankson, C. and Kalafatis, S.P. (2004), "The development and validation of a scale measuring consumer/customer-derived generic typology of positioning strategies", Journal of Marketing Management, Vol. 20 Nos 1/2, pp. 5-43.

Blankson, C. and Kalafatis, S.P. (2007), "Congruence between positioning and brand advertising", Journal of Advertising Research, Vol. 47 No. 1, pp. 79-94.

Blankson, C., Cowan, K., Crawford, J., Kalafatis, S., Singh, J. and Coffie, S. (2013), "A review of the relationships and impact of market orientation and market positioning on organisational performance", Journal of Strategic Marketing, Vol. 21 No. 6, pp. 499-512.

Boso, N., Story, V.M. and Cadogan, J.W. (2013), "Entrepreneurial orientation, market orientation, network ties, and performance: study of entrepreneurial firms in a developing economy", Journal of Business Venturing, Vol. 28 No. 6, pp. 708-727. 
Brady, M.K., Bourdeau, B.L. and Heskel, J. (2005), “The importance of brand cues in intangible service industries: an application to investment services", Journal of Services Marketing, Vol. 19 No. 6 , pp. 401-410.

Brik, A.B., Rettab, B. and Mellahi, K. (2011), "Market orientation, corporate social responsibility, and business performance”, Journal of Business Ethics, Vol. 99 No. 3, pp. 307-324.

Cadogan, J.W., Cui, C.C. and Kwok Yeung Li, E. (2003), "Export market-oriented behavior and export performance: the moderating roles of competitive intensity and technological turbulence", International Marketing Review, Vol. 20 No. 5, pp. 493-513.

Cano, C.R., Carrillat, F.A. and Jaramillo, F. (2004), "A meta-analysis of the relationship between market orientation and business performance: evidence from five continents", International Journal of Research in Marketing, Vol. 21 No. 2, pp. 179-200.

Cravens, D.W. (2000), Strategic Marketing, 6th ed., McGraw-Hill, Boston, MA.

Diamantopoulos, A. and Hart, S. (1993), "Linking market orientation and company performance: preliminary evidence on Kohli and Jaworski’s framework”, Journal of Strategic Marketing, Vol. 1 No. 2, pp. 93-121.

Fill, C. (1999), Marketing Communications, Context, Contents and Strategies, Prentice Hall, Upper Saddle River, NJ.

Fuchs, C. and Diamantopoulos, A. (2010), "Evaluating the effectiveness of brand-positioning strategies from a consumer perspective”, European Journal of Marketing, Vol. 44 Nos 11/12, pp. 173-1786.

Ghana Hotels Association (GHA) (2013), "Research report on the advocacy action for the development and enforcement of grading/operational criteria for hotel services in Ghana”, Final Report, GHA, Accra, Ghana.

Grinstein, A. (2008), "The relationships between market orientation and alternative strategic orientations: a meta-analysis”, European Journal of Marketing, Vol. 42 Nos 1/2, pp. 115-134.

Gruca, T.S. and Rego, L.L. (2005), "Customer satisfaction, cash flow, and shareholder value”, Journal of Marketing, Vol. 69 No. 3, pp. 1-130.

Gursoy, D., Chen, M.H. and Kim, H.J. (2005), "The US airlines relative positioning based on attributes of service quality", Tourism Management, Vol. 26 No. 1, pp. 57-67.

Hair, J.F., Andreson, R.E., Tatham, R.L. and Black, W.C. (1998), Multivariate Data Analysis, 5th ed., Prentice-Hall, Upper Saddle River, NJ.

Hair, J.F., Black, W.C., Babin, B.J., Anderson, R.E. and Tatham, R.L. (2006), Multivariate Data Analysis, Vol. 6, Pearson Prentice Hall, Upper Saddle River, NJ.

Hair, J.F., Wolfinbarger, M.F., Ortinau, D.J. and Bush, R.P. (2008), Essentials of Marketing Research, McGraw-Hill/Higher Education, Avenue of the Americas, New York, NY.

Hanson, B., Mattila, A.S., O’Neill, J.W. and Kim, Y. (2009), "Hotel rebranding and rescaling effects on financial performance", Cornell Hospitality Quarterly, Vol. 50 No. 3, pp. 360-370.

Haugland, S.A., Myrtveit, I. and Nygaard, A. (2007), "Market orientation and performance in the service industry: a data envelopment analysis", Journal of Business Research, Vol. 60 No. 11, pp. 1191-1197.

Hinson, R., Ofori, D., Kastner, A. and Mahmoud, M. (2008), "Market orientation and export performance: a Ghanaian study", African Journal of Business and Economic Research, Vol. 3 Nos 2/3, pp. 62-91.

Holloway, C.J. (2001), The Business of Tourism, 5th ed., Pearson Education Asia, Singapore.

Homburg, C. and Pflesser, C. (2000), "A multiple-layer model of market-oriented organizational culture: Measurement issues and performance outcomes", Journal of Marketing Research, Vol. 37 No. 4, pp. 449-462.

Hooley, G., Fahy, J., Cox, T., Beracs, J., Fonfara, K. and Snoj, B. (1999), "Marketing capabilities and firm performance: a hierarchical model”, Journal of Market-focused Management, Vol. 4 No. 3, pp. 259-278. 
IJCHM

29,10

\section{4}

Hooley, G., Fahy, J., Greenley, G., Beracs, J., Fonfara, K. and Snoj, B. (2003), "Market orientation in the service sector of the transition economies of central Europe", European Journal of Marketing, Vol. 37 Nos 1/2, pp. 86-106.

Hooley, G., Greenley, G., Fahy, J. and Cadogan, J. (2001), "Market-focused resources, competitive positioning and firm performance", Journal of Marketing Management, Vol. 17 Nos 5/6, pp. 503-520.

Hooley, G.J., Saunders, J.A. and Piercy, N. (2004), Marketing Strategy and Competitive Positioning, Pearson Education, Harlow Essex.

Hult, G.T.M. and Ketchen, D.J. (2001), "Does market orientation matter? A test of the relationship between positional advantage and performance”, Strategic Management Journal, Vol. 22 No. 9, pp. 899-906.

Kalafatis, S.P., Tsogas, M.H. and Blankson, C. (2000), "Positioning strategies in business markets", Journal of Business \& Industrial Marketing, Vol. 15 No. 6, pp. 416-437.

Kim, H.B. and Kim, W.G. (2005), "The relationship between brand equity and firms' performance in luxury hotels and chain restaurants", Tourism Management, Vol. 26 No. 4, pp. 549-560.

Kim, K.H., Kim, K.S., Kim, D.Y., Kim, J.H. and Kang, S.H. (2008), "Brand equity in hospital marketing”, Journal of Business Research, Vol. 61 No. 1, pp. 75-82.

Kim, W.G., Han, J.S. and Lee, E. (2001), "Effects of relationship marketing on repeat purchase and word of mouth", Journal of Hospitality \& Tourism Research, Vol. 25 No. 3, pp. 272-288.

Kirca, A.H., Jayachandran, S. and Bearden, W.O. (2005), "Market orientation: a meta-analytic review and assessment of its antecedents and impact on performance", Journal of Marketing, Vol. 69 No. 2, pp. 24-41.

Kohli, A.K. and Jaworski, B.J. (1990), "Market orientation: the construct, research propositions, and managerial implications", The Journal of Marketing, Vol. 54 No. 2, pp. 1-18.

Kotler, P. (2003), Marketing Insights from A to Z: 80 Concepts Every Manager Needs to Know, John Wiley \& Sons, Hoboken, NJ.

Kotler, P. and Keller, K.L. (2012), Marketing Management, 14th ed., Pearson Education, Upper Saddle River, NJ.

Kotler, P. and Armstrong, G. (2006), Principles of Marketing, Pearson Education, Upper Saddle River, NJ, pp. 217-218.

Kotler, P., Bowen, J.T. and Makens, J.C. (2010), Marketing for Hospitality and Tourism, 5th ed., Pearson Education, Upper Saddle River, NJ, p. 07458.

Kuada, J. and Buatsi, S.N. (2005), "Market orientation and management practices in Ghanaian firms: revisiting the Jaworski and Kohli framework", Journal of International Marketing, Vol. 13 No. 1, pp. 58-88.

Kuada, J. and Hinson, R. (2014), Service Marketing in Ghana, Adonis and Abbey Publishers, London.

Langerak, F. (2003), “An appraisal of research on the predictive power of market orientation”, European Management Journal, Vol. 21 No. 4, pp. 447-464.

Lee, J.S. and Back, K.J. (2010), "Examining antecedents and consequences of brand personality in the upper-upscale business hotel segment”, Journal of Travel \& Tourism Marketing, Vol. 27 No. 2, pp. 132-145.

McKitterick, J.B. (1958), What is the Marketing Management Concept? the Frontiers of Marketing Thought and Science, American Marketing Association, Chicago, IL.

Mahmoud, M.A. (2016), "Sustainable market orientation: a competitive strategic tool in an emerging economy context", Journal of Strategic Marketing, Vol. 1 No. 20.

Mahmoud, M.A. and Hinson, R.E. (2012), "Market orientation, innovation and corporate social responsibility practices in Ghana's telecommunication sector", Social Responsibility Journal, Vol. 8 No. 3, pp. 327-346. 
Mahmoud, M.A., Kastner, A. and Yeboah, J. (2010), "Antecedents, environmental moderators and consequences of market orientation: a study of pharmaceutical firms in Ghana", Journal of Medical Marketing: Device, Diagnostic and Pharmaceutical Marketing, Vol. 10 No. 3, pp. 231-244.

Malhotra, N.K. and Dash, S. (2011), Marketing Research an Applied Orientation, 6th ed., Pearson Prentice Hall, Delhi, pp. 170-203.

Mensah, I. (2006), "Environmental management practices among hotels in the greater Accra region", International Journal of Hospitality Management, Vol. 25 No. 3, pp. 414-431.

Mensah, I. and Blankson, E.J. (2013), "Determinants of hotels' environmental performance: evidence from the hotel industry in Accra, Ghana", Journal of Sustainable Tourism, Vol. 21 No. 8, pp. 1212-1231.

Miles, S.J. and Mangold, W.G. (2005), "Positioning Southwest airlines through employee branding", Business Horizons, Vol. 48 No. 6, pp. 535-545.

Mitchell, R.W., Wooliscroft, B. and Higham, J. (2010), "Sustainable market orientation: a new approach to managing marketing strategy", Journal of Macromarketing, Vol. 30 No. 2, pp. 160-170.

Morgan, N.A., Vorhies, D.W. and Mason, C.H. (2009), "Market orientation, marketing capabilities, and firm performance", Strategic Management Journal, Vol. 30 No. 8, pp. 909-920.

Narteh, B., Agbemabiese, G.C., Kodua, P. and Braimah, M. (2013), "Relationship marketing and customer loyalty: Evidence from the Ghanaian luxury hotel industry", Journal of Hospitality Marketing and Management, Vol. 22 No. 4, pp. 407-436.

Narver, J.C. and Slater, S.F. (1990), "The effect of a market orientation on business profitability", The Journal of Marketing, Vol. 54 No. 4, pp. 20-35.

Nicovich, S.G., Dibrell, C.C. and Davis, P.S. (2007), "Integration of value chain position and porter's (1980) competitive strategies into the market orientation conversation: an examination of uPstream and downstream activities", The Journal of Business and Economic Studies, Vol. 13 No. 2, p. 91.

Nunnally, J.C. (1978), Psychometric Theory, Mc Graw-Hill Publication, New York, NY.

O'neill, J.W. and Mattila, A.S. (2006), "Strategic hotel development and positioning the effects of revenue drivers on profitability", Cornell Hotel and Restaurant Administration Quarterly, Vol. 47 No. 2, pp. 146-154.

Olavarrieta, S. and Friedmann, R. (2008), "Market orientation, knowledge-related resources and firm performance", Journal of Business Research, Vol. 61 No. 6, pp. 623-630.

Porter, M.E. (1996), “What is strategy?”, Harvard Business Review, Vol. 74 No. 6, pp. 61-78.

Qu, R. (2009), "The impact of market orientation and corporate social responsibility on firm performance: evidence from China”, Asia Pacific Journal of Marketing and Logistics, Vol. 21 No. 4, pp. 570-582.

$\mathrm{Qu}, \mathrm{R}$. and Ennew, C.T. (2003), "An examination of the consequences of market orientation in China", Journal of Strategic Marketing, Vol. 11 No. 3, pp. 201-214.

Qu, R., Ennew, C. and Sinclair, M.T. (2005), "The impact of regulation and ownership structure on market orientation in the tourism industry in China", Tourism Management, Vol. 26 No. 6, pp. 939-950.

Raju, P.S., Lonial, S.C. and Crum, M.D. (2011), "Market orientation in the context of SMEs: a conceptual framework", Journal of Business Research, Vol. 64 No. 12, pp. 1320-1326.

Robson, C. (2002), Real World Research, Vol. 2, Blackwell Publishers, Oxford.

Sin, L.Y., A., C.B., Heung, V.C. and Yim, F.H. (2005), "An analysis of the relationship between market orientation and business performance in the hotel industry", International Journal of Hospitality Management, Vol. 24 No. 4, pp. 555-577.

Sørensen, H.E. (2009), "Why competitors matter for market orientation", European Journal of Marketing, Vol. 43 Nos 5/6, pp. 735-761. 
Spanos, Y.E. and Lioukas, S. (2001), "An examination into the causal logic of rent generation: contrasting Porter's competitive strategy framework and the resource-based perspective", Strategic Management Journal, Vol. 22 No. 10, pp. 907-934.

Tajeddini, K. (2010), "Effect of customer orientation and entrepreneurial orientation on innovativeness: evidence from the hotel industry in Switzerland", Tourism Management, Vol. 31 No. 2, pp. 221-231.

Urde, M., Baumgarth, C. and Merrilees, B. (2013), "Brand orientation and market orientation-from alternatives to synergy", Journal of Business Research, Vol. 66 No. 1, pp. 13-20.

Wang, C.H., Chen, K.Y. and Chen, S.C. (2012), "Total quality management, market orientation and hotel performance: the moderating effects of external environmental factors", International Journal of Hospitality Management, Vol. 31 No. 1, pp. 119-129.

Zhou, K.Z., Brown, J.R. and Dev, C.S. (2009), "Market orientation, competitive advantage, and performance: a demand-based perspective", Journal of Business Research, Vol. 62 No. 11, pp. 1063-1070.

Zikmund, G.W. and Babin, B.J. (2010), Essentials of Marketing Research, 4th ed., South Western Cengage Learning, Mason, $\mathrm{OH}$.

\section{Corresponding author}

Ibn Kailan Abdul-Hamid can be contacted at: ibnkailan@gmail.com

For instructions on how to order reprints of this article, please visit our website: 